\title{
Adverse pulmonary vascular effects of high dose tricyclic antidepressants: acute and chronic animal studies
}

\author{
X. Liu, C.J. Emery, E. Laude, J. Herget, G. Gill, G. Cope, G.R. Barer
}

\begin{abstract}
Adverse pulmonary vascular effects of high dose tricyclic antidepressants: acute and chronic animal studies. X. Liu, C.J. Emery, E. Laude, J. Herget, G. Gill, G. Cope, G.R. Barer. (C) ERS Journals Ltd 2002.

ABSTRACT: Overdose of tricyclic antidepressants, which inhibit cellular serotonin (5-HT) uptake, sometimes causes acute respiratory syndrome-like symptoms. Their acute and chronic cardiopulmonary actions, which might be implicated, utilising both in vivo and $e x$ vivo animal studies, were investigated in this study.

Acute amitriptyline (AMI), iprindole and imipramine caused dose-dependent prolonged rises in pulmonary artery pressure and oedema in anaesthetised cats in vivo. Acute AMI, in isolated $e x$ vivo blood-perfused rat lungs, also caused dosedependent sustained vasoconstriction, which could be attenuated with either calcium channel inhibition or a nitric oxide donor. It was demonstrated that the pressor effects of AMI were not due to release of histamine, serotonin, noradrenaline, or the activities of cycloxygenase or lipoxygenase. After AMI, hypoxic pulmonary vasoconstriction and the pressor actions of 5-HT and noradrenaline were diminished, possibly due to uptake inhibition. Activities of the endothelial-based enzymes, nitric oxide synthase and endothelin-converting enzyme, were undiminished. Large acute doses of AMI caused oedema with rupture of capillaries and alveolar epithelium.

Chronic iprindole raised pulmonary artery pressure and right ventricle (RV)/left ventricle (LV) + septal (S) weight. Chronic AMI led to attenuation of the pressor action of 5-HT, especially when associated with chronic hypoxic-induced pulmonary hypertension. $R V / L V+S$ weight increased, attributable to $\mathbf{L V}$ decline.
\end{abstract}

The acute and chronic effects observed might have relevance to clinical overdose, while the attenuation of acute effects offers possible therapeutic options. Eur Respir J 2002; 20: 344-352.
Respiratory Medicine, Division of Clinical Sciences (S) and "Dept of Biomedical Sciences, University of Sheffield, Sheffield, UK. "Dept of Physiology, 2nd Medical School, Prague, Czech Republic.

Correspondence: X. Liu, Respiratory Medicine, Floor F, Medical School, Beech Hill Rd, Sheffield, S10 2RX, UK

Fax: 441142711711

Keywords: Acute respiratory distress syndrome antidepressants

endothelium

lung

pulmonary

\section{Received: March 14200}

Accepted after revision: December 18 2001

This work was partly supported by a grant from the British Lung Foundation.
The tricyclic antidepressant (TCA) drugs, amitriptyline (AMI), iprindole and imipramine, are amphiphilic compounds with a hydrophobic ring structure and a primary or substituted amine side-chain bearing a net-positive charge. Their amphiphilic nature causes them to interact with phospholipids, producing generalised phospholipidosis when given chronically to rats and mice; foam cells were seen in the alveoli after chronic treatment with iprindole and imipramine but not with AMI [1]. These drugs affect serotonin (5-HT) uptake in cells, especially platelets. A high tissue/blood ratio has been reported for AMI, with the lung showing a high affinity for the drug [2]. TCAs show complex interactions with vasoactive autacoids. They are anticholinergic, prevent breakdown of noradrenaline (NA) and may inhibit synthesis of prostaglandins.

TCAs have chemical similarities with certain anorectic drugs, which also affect 5-HT transport and have been implicated as risk factors for primary pulmonary hypertension. In a parallel study, the current authors found that the anorectics fenfluramine and chlorphentermine have pulmonary vascular effects and influence certain endothelial functions [3].

TCAs are frequently used in self poisoning, particularly AMI. In the early stages, death commonly results from cardiac arrhythmias, but there are now many records of delayed death due to lung complications and radiography often shows lung damage in the early stages. However, there is no record of long-term pulmonary problems following prolonged treatment at normal dose levels.

The aim of this study was to establish the cardiopulmonary effects of TCAs which might underlie the clinical consequences of overdose. The study was conducted at two centres (University of Sheffield, Sheffield, UK and 2nd Medical School, Prague, Czech Republic). The acute pulmonary vascular actions of overdose levels of the antidepressants AMI, imipramine and iprindole, as well as the consequences of chronic treatment with AMI and iprindole, were examined.

\section{Methods}

\section{Ethical considerations}

This was a two-centre study. All procedures were performed in strict accordance with the regulations of the appropriate authorities. 


\section{Animals}

Cats (1.4-5.1 kg) were anaesthetised with chloralose (100 mg. $\mathrm{kg}^{-1}$ i.p.) and rats (Wistar strain, 200-350 g) with pentobarbitone $\left(60 \mathrm{mg} \cdot \mathrm{kg}^{-1} i_{i}\right.$. $)$. Heparin was given intravenously (1000 units $\left.\cdot \mathrm{kg}^{-1}\right)$.

\section{Cat left lower lobe preparation}

In anaesthetised, open-chest cats (ventilated with a Starling pump; Havard Instruments, Kent, UK), the left lower lobe of lung was perfused in vivo at a constant flow with autologous blood from the cannulated right atrium, as described previously [4]; thus, changes in pulmonary artery pressure $(P$ pa represented changes in pulmonary vascular resistance. Lobar flow was maintained at $100 \mathrm{~mL} \cdot \mathrm{kg}^{-1}(\sim 1 / 6 \mathrm{th}$ cardiac output), which resulted in pressure measurements within the normal range. The lobe was separately ventilated with a second Starling pump through the cannulated bronchus, and bronchial pressure was measured $(P$ br $)$. Left atrial pressure $(P$ la $)$ was measured from a cannula in the atrial appendage and systemic blood pressure $\left(P_{\text {sys }}\right)$ from a femoral cannula. TCAs were given i.v. in increasing doses; effects were prolonged, but further doses were delayed until initial conditions were restored. Saline control injections were given in all experiments and were without effect.

\section{Isolated ex vivo blood-perfused rat lungs}

After anaesthesia, rat lungs in situ were perfused with homologous blood at a constant flow $(20 \mathrm{~mL}$. $\min ^{-1}$ ) at $38^{\circ} \mathrm{C}$, as described previously [5]. After heparinisation the chest was opened with the lungs left in situ; the pulmonary artery and left atrium were cannulated and blood was circulated from a heated reservoir. $P$ pa was measured close to the cannulated pulmonary artery. The lungs were ventilated with air $+5 \%$ carbon dioxide $\left(\mathrm{CO}_{2}\right)$ (normoxia). Drugs were injected into the circuit close to the pulmonary artery and saline injections of equal volume were given as controls. Ventilation of the lung with an hypoxic gas ( $2 \%$ oxygen $\left.\left(\mathrm{O}_{2}\right)+5 \% \mathrm{CO}_{2}\right)$ caused a stable rise in $P$ pa (hypoxic pulmonary vasoconstriction (HPV)).

\section{Electron microscopy}

AMI (Roche, Hertfordshire, UK) was added into the circuit of the perfused rat lung. $P$ pa was monitored and the physiological effect was recorded. The lungs were then removed and perfused via the pulmonary artery, with glutaraldehyde at $20 \mathrm{mmHg}$ while the lung was inflated to $20 \mathrm{cmH}_{2} \mathrm{O}$, and processed for electron microscopy.

\section{Chronic amitriptyline and iprindole treatment}

Male litter mates were divided into treated and untreated groups.
Experiment 1: amitriptyline i.p. in normoxic rats. Eight rats received $25 \mathrm{mg} \cdot \mathrm{kg} \cdot \mathrm{day}^{-1}$ AMI i.p. and seven controls received equivolume isotonic saline $(0.9 \%$ $\mathrm{NaCl}$ ), for 15 days. After anaesthesia the $P$ pa was measured by cardiac catheterisation via the right jugular vein in the close-chested rat [6]. The heart was then removed and the right ventricle (RV)/left ventricle (LV)+septum (S) were weighed.

Experiment 2: amitryptyline i.p. in normoxic and chronically hypoxic rats. Groups of six rats were held in normoxia or chronic hypoxia in a normobaric environmental chamber for 21 days. The chamber, described previously [5], maintained $\mathrm{O}_{2}$ at $10 \%$ and $\mathrm{CO}_{2}$ stable at $\sim 0.2 \%$. Litters of six rats were split, three were put into the chamber and three were kept in the same room in air, three rats per cage. AMI, $25 \mathrm{mg} \cdot \mathrm{kg}^{-1}$, was given i.p. daily for 21 days and controls received saline. After treatment the isolated blood-perfused lung preparation was set up as described above. Pulmonary vascular resistance was calculated as the slope of the pressure/flow relationship. Briefly, the flow rate was reduced in a stepwise fashion $(20,15$, $10,5,0 \mathrm{~mL} \cdot \mathrm{min}^{-1}$ ) and the $P$ pa was allowed to stabilise. The extrapolated intercept on the pressure axis, derived from the linear portion of the relationship $\left(5-20 \mathrm{~mL} \cdot \mathrm{min}^{-1}\right)$, gave an indication of critical closure pressure. The pulmonary vascular response to 5-HT $(25,50 \mu \mathrm{g}$; Sigma, Poole, UK) and angiotensin I (AI, $0.5 \mu \mathrm{g}$; Sigma) was also recorded. Saline injections of a similar volume were given and were without effect.

Experiment 3: amitryptyline per os normoxic and chronically hypoxic rats. There were five rats in both the normoxic and chronic hypoxic groups. AMI, as a tryptazol paediatric syrup $\left(25 \mathrm{mg} \cdot \mathrm{kg} \cdot \mathrm{day}^{-1}\right.$; Royal Hallamshire Hospital, Sheffield, UK), was given by gavage for 21 days and controls received syrup alone. After anaesthesia, the lungs were fixed with $10 \%$ buffered formalin via the trachea at an inflation pressure of $20 \mathrm{cmH}_{2} \mathrm{O}$ for histological analysis, and $\mathrm{RV} / \mathrm{LV}+\mathrm{S}$ was measured as in Experiment 1.

Experiment 4: iprindole i.p. in normoxic rats. In Experiment $4 \mathrm{a}$, five rats received iprindole $\left(25 \mathrm{mg} \cdot \mathrm{kg} \cdot \mathrm{day}^{-1}\right.$ i.p.; Wyeth Laboratories, Hampshire, UK) and six rats received saline for 15 days. $P$ pa and $\mathrm{RV} / \mathrm{LV}+\mathrm{S}$ were measured as in Experiment 1.

In Experiment 4b, 10 rats received iprindole $\left(25 \mathrm{mg} \cdot \mathrm{kg} \cdot \mathrm{day}^{-1}\right.$ i.p. $)$ and nine rats saline for 15 days. $\mathrm{RV} / \mathrm{LV}+\mathrm{S}$ was measured as in Experiment 1.

\section{Light microscopy}

After wax embedding, $5 \mu \mathrm{m}$-thick sections were stained with Gomori's elastic stain to visualise the elastic laminae in the vascular wall. The development of a double elastic lamina enclosing new medial muscle is indicative of vascular remodelling associated with pulmonary hypertension. The percentage of small $(\leqslant 50 \mu \mathrm{m}$ diameter) pulmonary arterioles, adjacent to alveoli, with a double elastic laminae around $\geqslant 50 \%$ of the vessel circumference ( $\%$ thick walled 

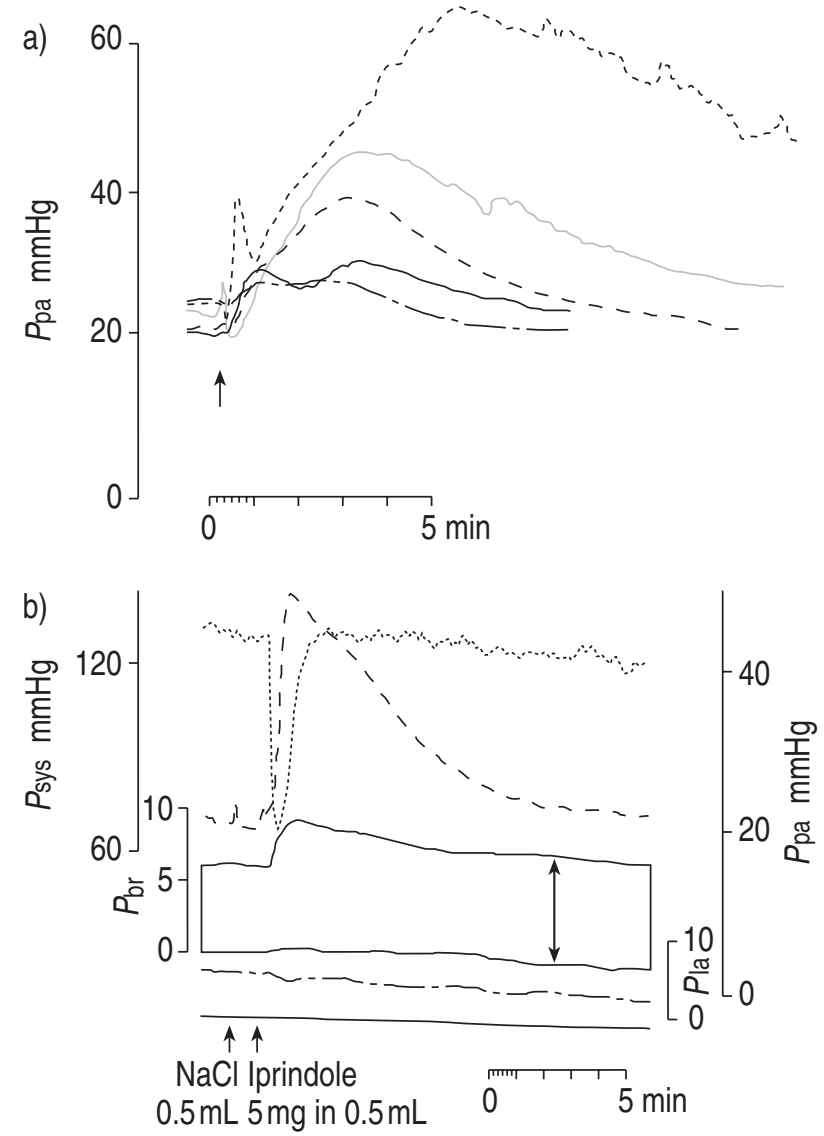

Fig. 1.- Traces of pulmonary artery pressure $(P \mathrm{pa})$ in a cat left lower lobe preparation with a constant blood flow. a) Successive doses of amitriptyline (AMI; $0.5(-), 1(--), 2(--), 5(-)$ and $10 \mathrm{mg}(\cdots)$; arrow indicates administration of drug) are superimposed. $P$ pa remains raised between doses. b) Iprindole causes a large persistent rise in $P_{\mathrm{pa}}(--)^{-}$, a transient fall in systemic blood pressure $\left(P_{\text {sys }} ; \cdots\right)$, a prolonged rise in bronchial airway pressure $(P \mathrm{br}$; double headed arrow), but negligible changes in left atrial pressure $(P \mathrm{la} ;---)$.

pulmonary vessels (\%TWPV) [7]) was ascertained under light microscopy (magnification $\times 400$ ). This method is capable of detecting small changes not detected by medial thickness measurements.

\section{Statistics}

Means and SEM were calculated and compared by paired and unpaired t-tests as appropriate. \%TWPV was assessed by the Mann-Whitney U-test. Differences were considered significant when $\mathrm{p}<0.05$.

\section{Results}

\section{Acute studies}

Cat left lower lobe preparation. AMI ( $\mathrm{n}=8,0.5-10 \mathrm{mg})$, iprindole $(\mathrm{n}=6,1-10 \mathrm{mg})$ and imipramine $(\mathrm{n}=3,1.25$ $12.5 \mathrm{mg}$ ), given into the inflow tubing to the lobar circuit, gave prolonged dose-dependent increases in $P$ pa and bronchoconstriction, and oedema often followed. Figure 1a shows superimposed traces of

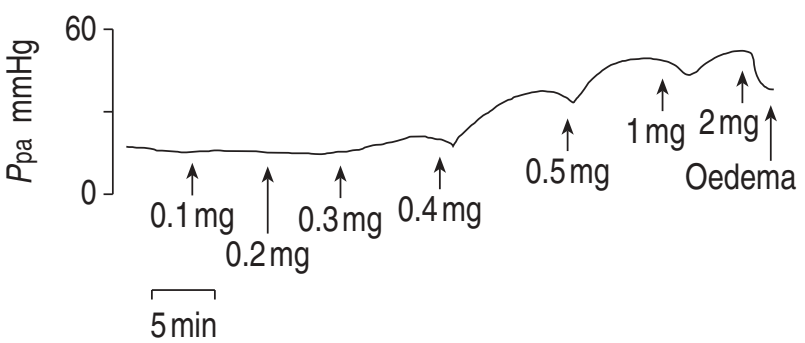

Fig. 2. - Trace of pulmonary artery pressure $(P$ pa $)$ in isolated perfused rat lung showing responses to successive doses of amitriptyline. The effects are cumulative. The final dose caused dilatation and oedema.

$P$ pa changes after $0.5-10 \mathrm{mg}$ AMI. Similar results followed treatment with iprindole and imipramine. Figure $1 \mathrm{~b}$ shows the effect of $5 \mathrm{mg}$ iprindole on $P$ pa, $P$ br, $P$ sys, $P$ la and flow to the lobe (constant). All three drugs led to changes in $P$ sys and $P$ br and occasional changes in $P$ la, which were insufficient to contribute to the large changes in $P$ pa. Similar volumes of saline were given in all experiments and had no pressor effect.

\section{Rat isolated ex vivo blood-perfused lung}

In seven rats, dose-response relationships were established using increasing doses of AMI (0.1, 0.2, $0.3,0.4,0.5,1,2$ and $5 \mathrm{mg}$ ) injected into the inflow tubing of the circuit (cumulative perfusate concentration $\left.3 \times 10^{-5}-2 \times 10^{-3} \mathrm{M}\right)$. They caused brief falls in $P$ pa, followed by persistent increases with doses $\geqslant 0.2 \mathrm{mg}$ (figs. 2 and 3). After large doses, further doses led to falls in $P$ pa and oedema often supervened. Oedema was not directly due to high $P$ pa as it also occurred when baseline $P$ pa was low (fig. 4). Similar volumes of saline had no pressor effect.

\section{Tests for endothelial function}

Angiotensin converting enzyme activity. Angiotensin converting enzyme (ACE) activity was tested with

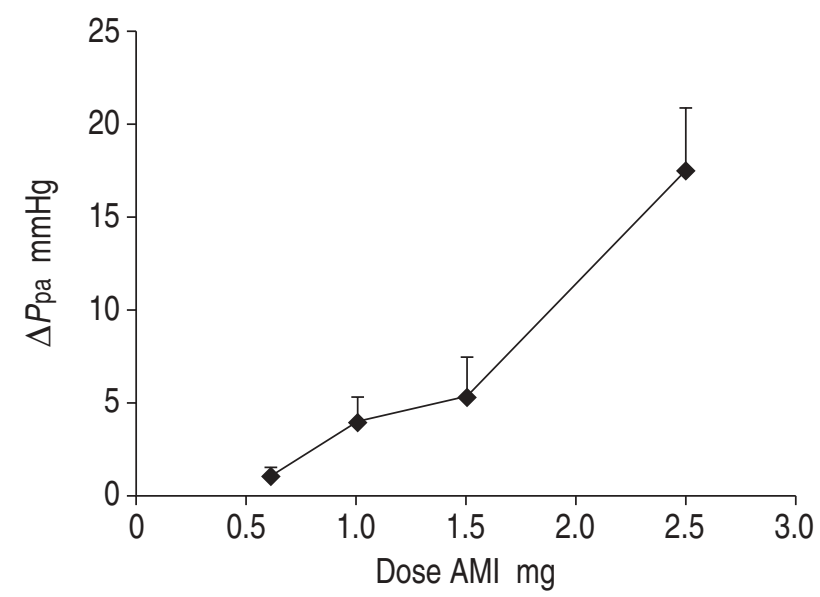

Fig. 3.- Mean cumulative rises in pulmonary artery pressure $(P$ pa $)$ after $0.6,1,1.5$ and $2.5 \mathrm{mg}$ amitriptyline (AMI) in seven rats. 


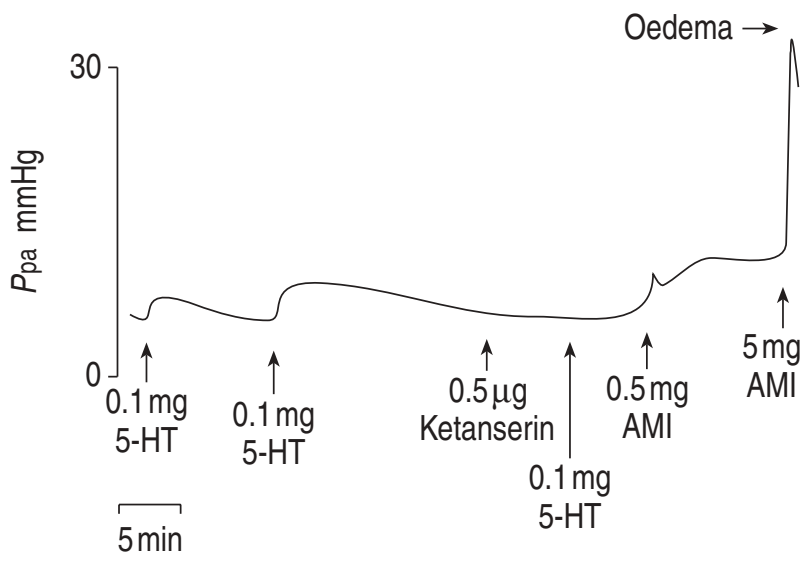

Fig. 4.-Trace of pulmonary artery pressure $(P$ pa $)$ in an isolated rat lung showing abolition of the pressor response to serotonin $(5-\mathrm{HT})$ by ketanserin. Subsequently, there is a large rise in $P_{\mathrm{pa}}$ after $0.5 \mathrm{mg}$ amitriptyline (AMI) and a huge rise, leading to oedema, after $5 \mathrm{mg}$ AMI.

angiotensin $\mathrm{I}(\mathrm{AI}, \mathrm{n}=4)$ and bradykinin $(\mathrm{BK}, \mathrm{n}=4)$. Neither activity was altered after AMI $(0.5 \mathrm{mg})$. AI $(0.5 \mu \mathrm{g}$, repeated twice) caused rises in $P$ pa of $5.8 \pm 0.9$ before and $7.4 \pm 1.6 \mathrm{mmHg}$ after AMI (NS). BK (10 $\mu \mathrm{g}$, twice) caused rises in $P$ pa of $8.7 \pm 1.1$ before and $8.3 \pm 1.1 \mathrm{mmHg}$ after AMI (Ns).

Endothelin converting enzyme and nitric oxide synthase activity. There was no evidence that either endothelin converting enzyme or nitric oxide synthase (NOS) activity was reduced after AMI. Big endothelin-1 $(1 \mu \mathrm{g}$; Sigma) caused a similar rise in $P$ pa either in the presence $(\mathrm{n}=5)$ or absence $(\mathrm{n}=5)$ of $0.5 \mathrm{mg}$ AMI $(\Delta P \mathrm{pa}$ $5.7 \pm 2.0 \mathrm{mmHg}$ versus $2.8 \pm 0.4 \mathrm{mmHg}$, Ns). The rise in $P$ pa with $100 \mu \mathrm{g}\left(1 \times 10^{-5} \mathrm{M}\right) N$-nitro-L-arginine methyl ester (L-NAME) in the presence of AMI (fig. 5a) $(\Delta P$ pa $5.2 \pm 1.6 \mathrm{mmHg})$ suggests that AMI stimulated NOS activity, because L-NAME does not usually cause substantial rises in $P$ pa in normal rat lungs during normoxia [8].

Pressor effects of amines. 5-HT $(100 \mu \mathrm{g})$, given twice with reproducible results, caused a rise in $P$ pa of $8.9 \pm$ $1.9 \mathrm{mmHg}$ before but a significantly smaller rise of $1.7+0.05 \mathrm{mmHg}$ after $0.5 \mathrm{mg}$ AMI $(\mathrm{n}=6, \mathrm{p}<0.05)$. Similarly, NA $(100 \mu \mathrm{g})$ was given twice before and twice after $0.5 \mathrm{mg}$ AMI. The pressor response was reduced $(\Delta P$ pa $1.0 \pm 0.8 \mathrm{mmHg}$ before, $0.06 \pm 0.05 \mathrm{mmHg}$ after AMI $\mathrm{p}<0.05, \mathrm{n}=4$, fig. $5 \mathrm{~b})$.

\section{Effect on hypoxic pulmonary vasoconstriction}

A reproducible HPV (rise in $P$ pa) was established after 2-3 hypoxic challenges (fig. 5a). Subsequently, $0.5 \mathrm{mg}$ AMI, which caused a persistent stable rise in $P$ pa, reduced HPV. With hypoxia, $P$ pa rose $7.3 \pm 1.8 \mathrm{mmHg}$ before and $2.7 \pm 0.7 \mathrm{mmHg}$ after AMI $(\mathrm{p}<0.05)$. After the addition of $100 \mu \mathrm{g}$ $\left(1 \times 10^{-5} \mathrm{M}\right)$ L-NAME, HPV was restored (fig 5a).
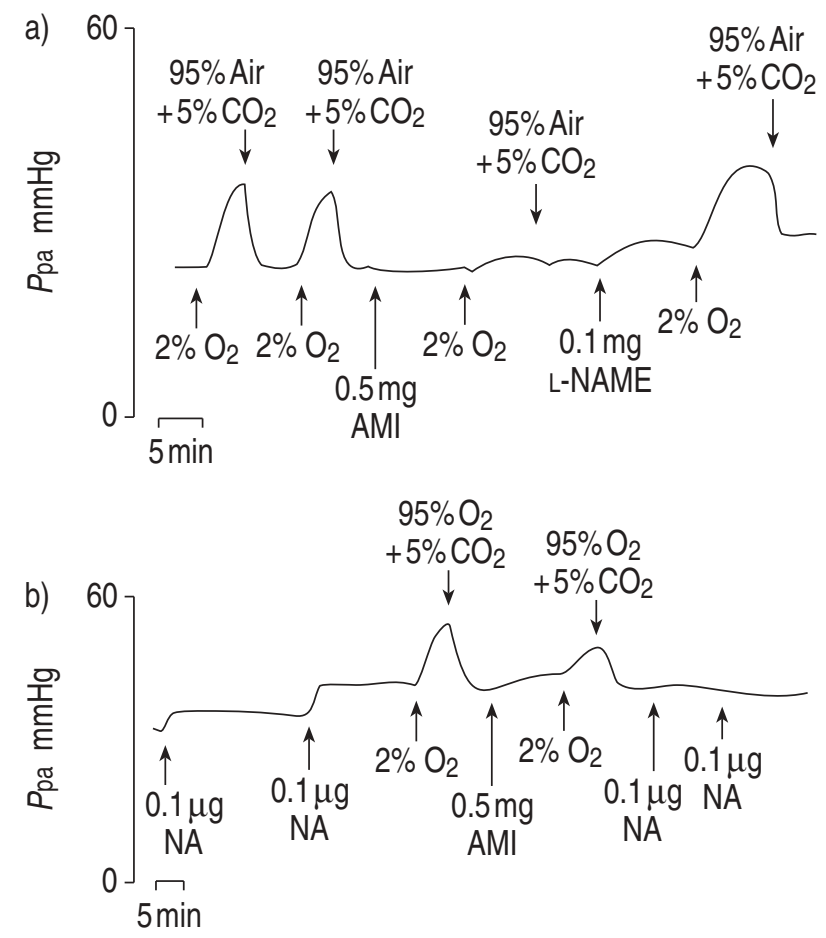

Fig. 5. - a) Trace of pulmonary artery pressure $\left(P_{\mathrm{pa}}\right)$ in a rat lung showing that the pressor effect of hypoxia $\left(2 \%\right.$ oxygen $\left(\mathrm{O}_{2}\right)+5 \%$ carbon dioxide $\left.\left(\mathrm{CO}_{2}\right)\right)$ is greatly reduced after amitriptyline (AMI). In this rat, AMI caused dilatation only. After AMI, $N$-nitroL-arginine methyl ester (L-NAME, $100 \mu \mathrm{g}, 1 \times 10^{-5} \mathrm{M}$ ) caused a rise in $P$ pa. Subsequently, the pressor response to hypoxia was greatly increased. b) Trace of $P$ pa in a rat lung showing persistent large

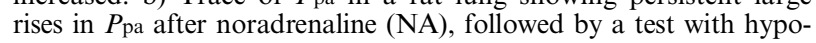
xia. After AMI, which caused only a small rise in $P_{\mathrm{pa}}$, the effect of hypoxia was reduced and the response to NA was negligible.

Unusually, AMI caused only a small dilatation and no constriction.

\section{Tests for secondary release of autacoids by amitryptyline}

The pressor/dilator action of AMI could not be inhibited with inhibitors of potential mediator receptor/enzymes (table 1). These included: cyclooxygenase with meclofenamate $\left(100 \mu \mathrm{g}, 1 \times 10^{-5} \mathrm{M}\right)$, which blocked the pulmonary vasomotor effects of arachidonic acid [9]; lipoxygenase with diethylcarbamazine (DEC) $(20 \mathrm{mg}, 5 \times 10 \mathrm{M})$, which abolished $\mathrm{HPV} ; \alpha$-adrenoreceptors with phentolamine $(0.2 \mathrm{mg}$, $\left.1 \times 10^{-5} \mathrm{M}\right)$, which abolished the pressor effect of NA; and 5-HT receptors with ketanserin $\left(1 \times 10^{-5} \mathrm{M}\right)$, which abolished the pressor effect of 5-HT (fig. 4). Histamine $\mathrm{H} 1$ and $\mathrm{H} 2$ blockade was achieved with piriton $\left(1 \mathrm{mg}, 3 \times 10^{-4} \mathrm{M}\right)$ and cimetidine $(2.5 \mathrm{mg}$, $\left.8 \times 10^{-4} \mathrm{M}\right)$ in doses found to be effective in previous studies [10]. Due to persistence of response, AMI was only given after the addition of the inhibitor into the blood perfusate. Table 1 shows that the increases in $P$ pa with AMI were within the normal range and that oedema still followed large doses. DEC (20 mg, $\left.5 \times 10^{-4} \mathrm{M}\right)$, given after the rise in $P$ pa caused by AMI, 
Table 1.-Effect of mediator receptor/enzyme blockade on the pressor response to amitriptyline (AMI) in isolated blood perfused rat lungs

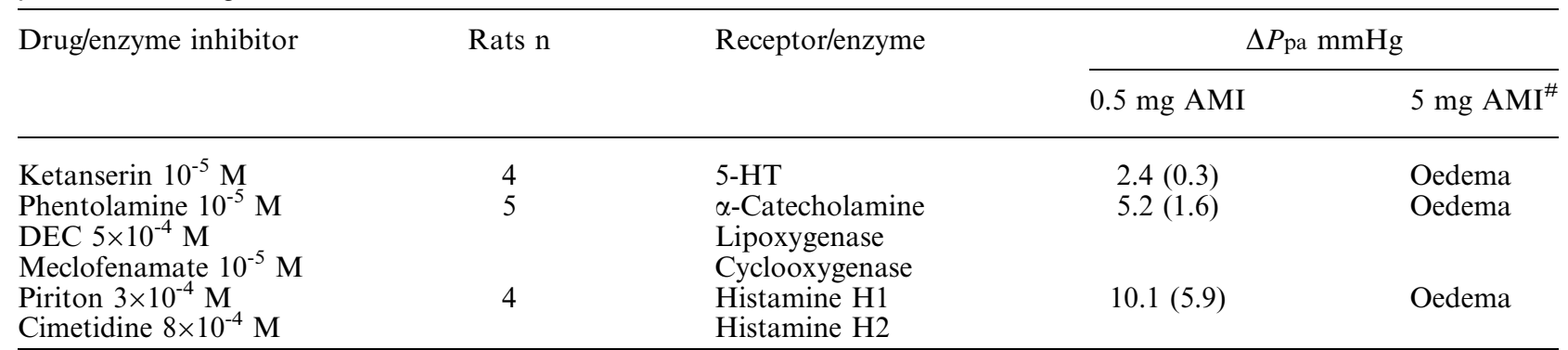

Data are presented as mean (SEM) or $\mathrm{n}$ rats. $\triangle P$ pa: rise in pulmonary artery pressure; DEC: diethylcarbamazine; 5-HT: serotonin. ${ }^{\#}$ : $5 \mathrm{mg}$ caused a large rise in $P$ pa followed by oedema.

did not reduce $P$ pa but caused a further rise (2.0 $\pm 0.7 \mathrm{mmHg}, \mathrm{n}=4)$ (fig. 6).

\section{Effect of dilator drugs after amitryptyline}

The effect of s-Nitroso- $N$-acetylpenicillamine (SNAP, NO donor; Tocris Pharmaceuticals, Avonmouth, UK) and verapamil $\left(\mathrm{Ca}^{2+}\right.$ channel inhibitor; Abbott Laboratories, IL, USA) on $P$ pa, after $P$ pa was raised with $0.5 \mathrm{mg}$ AMI, was tested (fig. 7). SNAP (100 $\mu \mathrm{g}$, $5 \times 10^{-5} \mathrm{M}, \mathrm{n}=4$ ) caused a large reduction in $P$ pa after AMI, $-9.8 \pm 1.8 \mathrm{mmHg}$. Verapamil $\left(100 \mu \mathrm{g}, 1 \times 10^{-5} \mathrm{M}\right.$, $\mathrm{n}=7)$ also reduced $P$ pa after AMI, $-3.2 \pm 0.4 \mathrm{mmHg}$.

\section{Electron microscopy after acute amitryptyline}

Electron micrographs, taken from rat lungs treated acutely with medium $(200 \mu \mathrm{g})$ and large $(4 \mathrm{mg})$ doses of AMI, showed damage to the alveolar lining and alveolar capillary endothelium (fig. 8). There was distension and rupture of capillaries and oedema and red blood cells in the alveolar space; alveolar lining cells were displaced by oedema and formed bullae projecting into the alveoli.

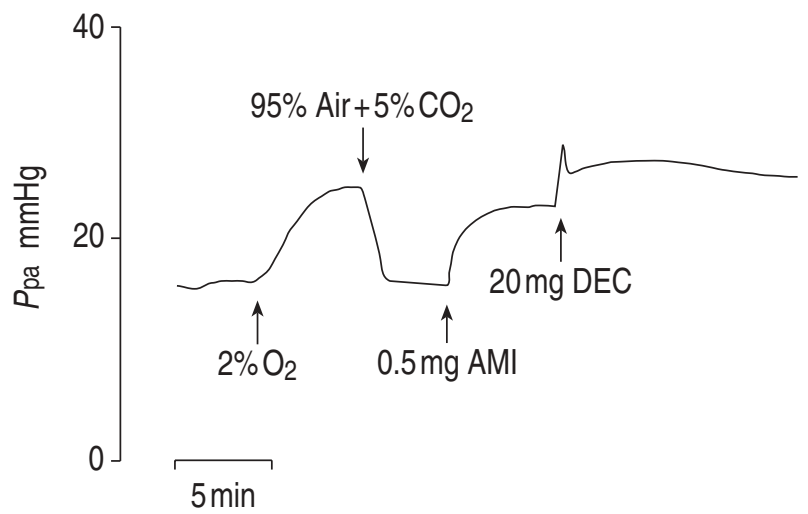

Fig. 6.- Trace of the effect of diethylcarbamazine (DEC) after amitriptyline (AMI). P pa: pulmonary artery pressure; $\mathrm{O}_{2}$ : oxygen; $\mathrm{CO}_{2}$ : carbon dioxide.

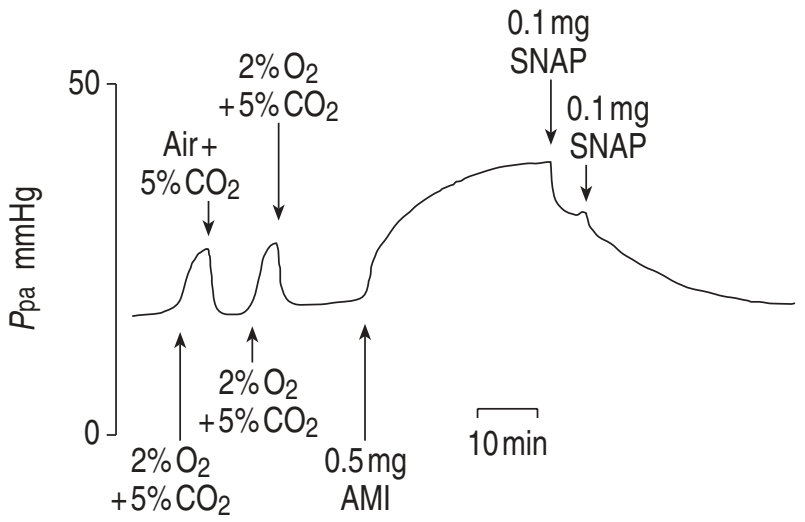

Fig. 7. - Trace of the dilator action of s-Nitroso- $N$-acetylpenicillamine (SNAP) $\left(5 \times 10^{-5} \mathrm{M}\right)$, after pulmonary artery pressure $(P \mathrm{pa})$ was raised by amitriptyline (AMI). $\mathrm{O}_{2}$ : oxygen; $\mathrm{CO}_{2}$ : carbon dioxide.

\section{Chronic studies}

Chronic amitriptyline. Experiment 1 (table 2). AMItreated rats had a tendency to higher $P$ pa, but the difference was not significant. $\mathrm{RV} / \mathrm{LV}+\mathrm{S}$ was significantly raised in the AMI group. Absolute RV weight was unchanged but $\mathrm{LV}+\mathrm{S}$ weights were reduced and account for the increase in the $\mathrm{RV} / \mathrm{LV}+\mathrm{S}$ ratio. The treated rats were in poor condition, which may have affected cardiac output and $P$ pa.

Experiment 2 (table 3). AMI treatment had no effect on indices of pulmonary hypertension, i.e. slope of the pressure/flow (P/Q) line or intercept. Chronic hypoxic rats had steeper P/Q lines, higher intercepts on the $P$ pa axis and increased pressor responses to AI, as previously reported [5]. The only difference in vasoreactivity observed between AMI and salinetreated rats was that chronic hypoxic AMI-treated rats had significantly reduced responses to 25 and $50 \mu \mathrm{g}$ 5-HT; the saline-treated chronic hypoxic rats had greater pressor responses to 5-HT than normoxic rats. AMI-treated normoxic rats also had reduced responses to 5-HT compared with saline-treated controls (NS).

Experiment 3 (table 3). The \%TWPV was not significantly altered by AMI treatment. In normoxic groups, unlike Experiment 1, neither absolute RV or 

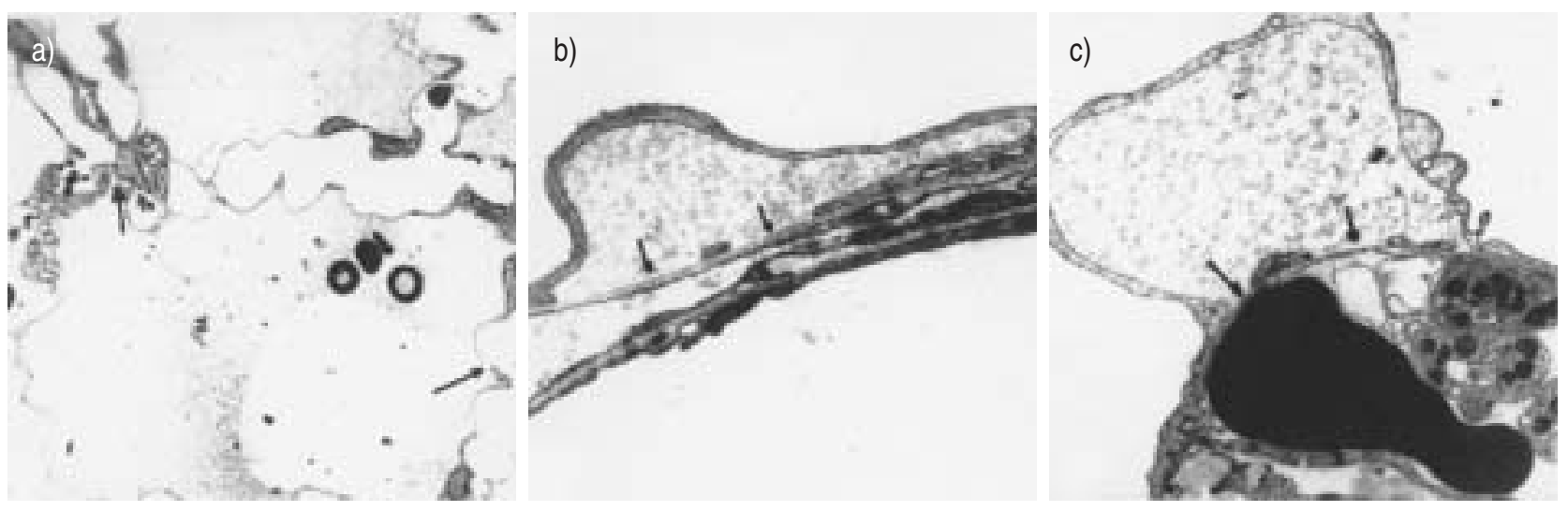

Fig. 8.-Electron micrographs after amitriptyline (AMI) administration to isolated rat lungs. After 4 mg AMI (a), the capillaries in the alveolar walls have dilated and have ruptured (arrows); fluid and red blood cells are present in alveolar space. After $200 \mu \mathrm{g}$ AMI (b and c), type 1 cells have detached from the basal lamina and blebs protrude into the alveolar space.

$\mathrm{LV}+\mathrm{S}$ weights or $\mathrm{RV} / \mathrm{LV}+\mathrm{S}$ ratio were significantly altered by AMI treatment. However, there was evidence of a significant reduction in $\mathrm{LV}+\mathrm{S} /$ body weight (BW) in the treated group $(\mathrm{LV}+\mathrm{S} / 100 \mathrm{~g} \mathrm{BW} 0.22 \pm$ 0.002 and $0.21 \pm 0.003$ untreated versus treated, respectively $\mathrm{p}<0.001)$. These rats were in better condition than those given AMI i.p. (Experiment 2).

Chronic hypoxia caused RV hypertrophy and an increase in $\mathrm{RV} / \mathrm{LV}+\mathrm{S}$ with no change in $\mathrm{LV}+\mathrm{S} / \mathrm{BW}$, and an increase in \%TWPV. There was no difference between AMI treated and untreated groups.

\section{Chronic iprindole}

Experiment $4 \mathrm{a}$ (table 4). $P$ pa and $\mathrm{RV} / \mathrm{LV}+\mathrm{S}$ were raised after chronic iprindole treatment and $\mathrm{BW}$ was reduced $(\mathrm{p}<0.01)$.

Experiment $4 \mathrm{~b}$ (table 4$)$. $\mathrm{RV} / \mathrm{LV}+\mathrm{S}$ was raised after treatment although not quite to significance $(\mathrm{p}=0.053)$, BW was reduced $(\mathrm{p}<0.001)$. Although the absolute $\mathrm{LV}+\mathrm{S}$ was significantly reduced $(\mathrm{p}<0.001)$, when LV was expressed per BW there was no difference between

Table 2.-Effect of chronic amitriptyline treatment on indices of pulmonary hypertension in the rat

\begin{tabular}{llc}
\hline & Saline & Amitriptyline \\
\hline Experiment $1^{\#}$ & & \\
Rats n & 7 & 8 \\
$\mathrm{BW} \mathrm{g}$ & $236(2)$ & $284(10)$ \\
$\mathrm{RV} \mathrm{mg}$ & $157(56)$ & $139(18)$ \\
$\mathrm{S} \mathrm{mg}$ & $145(5.4)$ & $99(8.8)^{* * * *}$ \\
$\mathrm{LV} \mathrm{mg}$ & $403(14)$ & $249(18)^{* * *}$ \\
$\mathrm{RV} / \mathrm{LV}+\mathrm{S}$ & $0.29(0.005)$ & $0.45(0.007)^{*}$ \\
$P$ pa $\mathrm{mmHg}$ & $15.4(0.6)$ & $18.8(1.5)$ \\
\hline
\end{tabular}

Data are presented as mean (SEM) or $\mathrm{n}$ of rats. BW: final body weight; RV: right ventricle; LV: left ventricle; S: septum; Ppa: pulmonary artery pressure. *: $\mathrm{p}<0.05$; ***: $\mathrm{p}<0.001$ versus saline treated group; ${ }^{\#}:$ chronic amitriptyline treatment $25 \mathrm{mg} \cdot \mathrm{kg} \cdot \mathrm{day}^{-1}$ for 15 days; ${ }^{\uparrow}: \mathrm{n}=5$. treated and untreated groups $(\mathrm{LV}+\mathrm{S} / 100 \mathrm{~g} \mathrm{BW}$, control $0.23 \pm 0.003$ versus iprindole $0.22 \pm 0.006$, NS).

\section{Discussion}

\section{Main findings}

In this study, acute administration of overdose levels of the TCAs AMI, imipramine and iprindole caused persistent rises in $P$ pa in cats in vivo. This pressor effect of AMI, studied in ex vivo bloodperfused isolated rat lungs, was not due to release of histamine, NA, 5-HT, products of cyclooxygenase or lipoxygenase but could be reduced by calcium channel inhibition or an nitric oxide (NO) donor. Chronic AMI reduced pulmonary vascular responses to the biogenic amines 5-HT and NA. Although this may be due to a direct effect on amine receptors responsible for vasoconstriction, another possible mechanism is the inhibition of amine uptake by pulmonary endothelium. Chronic treatment with iprindole, but not AMI, led to pulmonary hypertension.

\section{Overdose of tricyclic antidepressants}

Self-poisoning by TCAs is common and increasing. Although cardiac complications are the common cause of death, some delayed fatal pulmonary complications were reported in the 1970s [11, 12]. The lung accumulates these drugs $[2,13]$ and more recent large surveys have shown that lung radiological changes are frequent and may be an early development. VARNELL et al. [14] reviewed 81 cases of TCA overdose (20 cases with AMI). Fifty-four per cent had radiological abnormalities in the lung while $9 \%$ had clinical and radiological changes consistent with acute respiratory distress syndrome (ARDS). Aspiration could account for some effects. Roy et al. [15] surveyed 82 consecutive patients with TCA overdose. The ratio of arterial to alveolar oxygen pressure was reduced and mechanical ventilation was required in $77 \%$. Nearly half showed lung radiological abnormalities 
Table 3. - Effect of chronic amitriptyline on pulmonary vascular resistance and response to vasoconstrictors (Experiment 2) and indices of pulmonary hypertension (Experiment 3 ) in ex vivo isolated blood-perfused rat lungs

\begin{tabular}{|c|c|c|c|c|}
\hline & $\mathrm{CS}$ & CA & CHS & CHA \\
\hline \multicolumn{5}{|l|}{ Experiment $2^{\bullet}$} \\
\hline BW g & $\begin{array}{c}308(5) \\
(\mathrm{n}=6)\end{array}$ & $\begin{array}{c}296(17) \\
(\mathrm{n}=6)\end{array}$ & $\begin{array}{c}184(11)^{* *} \\
(\mathrm{n}=6)\end{array}$ & $\begin{array}{c}190(10)^{* *} \\
(\mathrm{n}=6)\end{array}$ \\
\hline $\mathrm{PVR} \mathrm{mmHg} \cdot \mathrm{mL} \cdot \mathrm{min}^{-1}$ & $\begin{array}{c}0.63(0.07) \\
(\mathrm{n}=6)\end{array}$ & $\begin{array}{c}0.57(0.06) \\
(\mathrm{n}=6)\end{array}$ & $\begin{array}{c}0.81(0.07)^{*} \\
(\mathrm{n}=3)\end{array}$ & $\begin{array}{c}0.87(0.09)^{*} \\
(\mathrm{n}=6)\end{array}$ \\
\hline Intercept $\mathrm{mmHg}$ & $\begin{array}{c}5.8(0.2) \\
(\mathrm{n}=6)\end{array}$ & $\begin{array}{c}5.1(0.6) \\
(\mathrm{n}=5)\end{array}$ & $\begin{array}{c}8.6(0.8) \\
(n=3)\end{array}$ & $\begin{array}{c}7.3(0.2)^{\#} \\
(\mathrm{n}=6)\end{array}$ \\
\hline \multicolumn{5}{|l|}{$\Delta P$ pa $\mathrm{mmHg}$} \\
\hline $2 \% \mathrm{O}_{2}^{\S}$ & $\begin{array}{c}11.1(1.7) \\
(\mathrm{n}=6)\end{array}$ & $\begin{array}{l}8.2(1.5) \\
(\mathrm{n}=5)\end{array}$ & $\begin{array}{c}14.0(4.4) \\
(\mathrm{n}=5)\end{array}$ & $\begin{array}{c}9.8(0.53) \\
\quad(n=6)\end{array}$ \\
\hline $25 \mu \mathrm{g} \mathrm{5-HT}$ & $\begin{array}{c}6.6(2.2) \\
(n=6)\end{array}$ & $\begin{array}{c}2.2(0.5) \\
(\mathrm{n}=5)\end{array}$ & $\begin{array}{c}14.6(3.5)^{*} \\
(\mathrm{n}=5)\end{array}$ & $\begin{array}{c}5.0(1.2)^{\#} \\
(\mathrm{n}=6)\end{array}$ \\
\hline $50 \mu \mathrm{g} \mathrm{5-HT}$ & $\begin{array}{c}7.98(2.7) \\
(n=6)\end{array}$ & $\begin{array}{c}3.9(1.2) \\
(n=5)\end{array}$ & $\begin{array}{c}24.8(3.1)^{* * * *} \\
(\mathrm{n}=5)\end{array}$ & $\begin{array}{c}11.1{ }_{(\mathrm{n}=6)}^{(2.7)^{*}, \# \#}\end{array}$ \\
\hline $0.5 \mu \mathrm{g} \mathrm{AI}$ & $\begin{array}{c}13.1(1.2) \\
(n=5)\end{array}$ & $\begin{array}{c}12.4(3.6) \\
(\mathrm{n}=4)\end{array}$ & $\begin{array}{c}30.9(5.3)^{* *} \\
(\mathrm{n}=5)\end{array}$ & $\begin{array}{c}33.6(2.6)^{* * *} \\
(\mathrm{n}=6)\end{array}$ \\
\hline \multicolumn{5}{|l|}{ Experiment $3^{+}$} \\
\hline Rats n & 4 & 4 & 5 & 5 \\
\hline BW g & $276(5)$ & $293(16)$ & $263(11)$ & $250(4)^{* *}$ \\
\hline $\mathrm{RV} / \mathrm{LV}+\mathrm{S}$ & $0.20(0.008)$ & $0.22(0.01)$ & $0.50(0.02)^{*}$ & $0.47(0.02)^{*}$ \\
\hline RV mg & $120(6)$ & $135(12)$ & $289(26)^{* * *}$ & $291(13)^{* *}$ \\
\hline $\mathrm{LV}+\mathrm{S} \mathrm{mg}$ & $613(7)$ & $611(32)$ & $621(41)$ & $586(27)$ \\
\hline$\%$ TWPV & $15(5.8)$ & $13(1.8)$ & $41(7.3)^{*}$ & $44(4.3)^{*}$ \\
\hline
\end{tabular}

Data are presented as mean (SEM) and $\mathrm{n}$ of rats. CS: normoxic rats treated with saline; CA: normoxic rats treated with amitriptyline; CHS: chronically hypoxic rats (3 weeks, $\left.10 \% \mathrm{O}_{2}\right)$, saline; CHA: chronically hypoxic rats $\left(3\right.$ weeks, $\left.10 \% \mathrm{O}_{2}\right)$, amitriptyline; BW: final body weight; PVR: pulmonary vascular resistance; $\Delta P$ pa: rise in pulmonary artery pressure; $\mathrm{O}_{2}$ : oxygen; 5-HT: serotonin; AI: angiotensin-I; RV: right ventricle; LV: left ventricle; S: septum; \% TWPV: \% thick walled pulmonary vessels. ${ }^{*}: \mathrm{p}<0.05 ;{ }^{* *}: \mathrm{p}<0.01 ;^{* * *}: \mathrm{p}<0.001$ chronic hypoxia versus normoxia; ${ }^{\#}: \mathrm{p}<0.05$; $^{\# \#}: \mathrm{p}<0.01$ amitriptyline treated versus saline treated; ${ }^{\uparrow}: 25 \mathrm{mg} \cdot \mathrm{kg} \cdot \mathrm{day}^{-1}$ amitriptyline i.p. for 21 days, controls received saline; ${ }^{+}: 25 \mathrm{mg} \cdot \mathrm{kg} \cdot \mathrm{day}{ }^{-1}$ tryptazol (syrup) per os by gavage for 21 days, controls received syrup alone; ${ }^{\S}$ : in this Wistar strain hypoxic pulmonary vasoconstriction in chronic hypoxic rat lungs is large [5].

within the first $48 \mathrm{~h}$. In 56 consecutive cases, SHANNON et al. [16] also found a high frequency $(30 \%)$ of abnormal lung radiography. It is therefore emerging that understanding the pulmonary

Table 4.-Effect of chronic iprindole treatment on indices of pulmonary hypertension in the rat

\begin{tabular}{lcc} 
& Saline & Iprindole \\
\hline Experiment $4 \mathrm{a}^{\bullet}$ & & \\
Rats n & 6 & 5 \\
$\mathrm{BW} \mathrm{g}$ & $290(12)$ & $232(20)^{* *}$ \\
$\mathrm{RV} \mathrm{mg}$ & $84(3)$ & $120(14)^{*}$ \\
LV+S mg & $420(12)$ & $423(26)$ \\
RV/LV+S mg & $0.20(0.005)$ & $0.28(0.018)^{* *}$ \\
$P$ pa mmg & $16.0(0.1)$ & $24(0.18)^{* *}$ \\
Experiment 4b & & \\
Rats n & 9 & 10 \\
BW g & $283(6)$ & $234(5)^{* * *}$ \\
RV mg & $155(6)$ & $142(11)$ \\
LV+S mg & $646(16)$ & $515(18)^{* * *}$ \\
RV/LV+S & $0.24(0.006)$ & $0.28(0.017)^{\#}$ \\
\hline
\end{tabular}

Data are presented as mean (SEM) or $\mathrm{n}$ of rats. BW: final body weight; RV: right ventricle; LV: left ventricle; S: septum; $P$ pa: pulmonary artery pressure. *: $\mathrm{p}<0.05 ; * *: \mathrm{p}<0.01 ; * * *$ : $\mathrm{p}<0.001$ versus saline treated group; ${ }^{\#}: \mathrm{p}=0.05 ;$ ": chronic iprindole treatment $25 \mathrm{mg} \cdot \mathrm{kg} \cdot \mathrm{day}^{-1}$ i. $p$. for 15 days, a and $\mathrm{b}$ are different experiments with the same dosage regime. changes and looking for suitable treatment is of great importance.

\section{Acute administration of amitriptyline}

Several of the acute effects observed with AMI in both cats in vivo and ex vivo isolated rat lungs may be relevant to the clinical problems seen after overdose [17]. Persistent raised $P$ pa, oedema and suppression of hypoxic vasoconstriction was found. The latter could have serious consequences through impairment of ventilation/perfusion ratio matching when the lung is patchily affected. Depression of HPV may have been due to increased activity of endothelial NOS. It would be valuable to find out whether inducible NOS, which may be responsible for some aspects of ARDS, becomes expressed in these conditions. Evidence that AMI impaired the pressor action of both 5-HT and NA in rat lungs was found. TCA drugs inhibit uptake of 5-HT and NA, although this is through separate transporter mechanisms [18]. Systemic consequences of impaired amine clearance by the lung in TCA overdose could be important. It is known that catecholamine blood levels are raised in TCA overdose; this in turn might lead to the lipid disturbances which have been observed.

The electron micrographs in this study showed that one large acute dose of AMI could cause rupture of 
the alveolar lining, breaks in capillary endothelium and fulminant oedema. However, a smaller dose, although sufficient to cause some ultrastructural damage, did not impair endothelial enzyme activity (endothelial NOS, cyclooxygenase and endothelin converting enzyme).

The rise in $P$ pa with acute doses of AMI could be reduced substantially by addition of either a calcium channel inhibitor or an NO donor, suggesting that these changes are reversible and thus treatable.

\section{Chronic treatment with amitriptyline}

Impaired 5-HT pressor responses persisted after chronic treatment with AMI. The rise in $P$ pa after 5-HT was reduced, significantly in chronic hypoxic rats where vasoreactivity was increased; HPV and AI responses were maintained (table 3 ).

In Experiment 1, where AMI was given i.p. (table 2) there was no unequivocal evidence for pulmonary hypertension. Mean $P$ pa was raised but not significantly. The raised $\mathrm{RV} / \mathrm{LV}+\mathrm{S}$ ratio was most likely due to the reduction in $\mathrm{LV}$ weight as $\mathrm{RV}$ weight was not increased. Although there was no direct evidence, it is possible that the poor condition of the treated rats, with abdominal distension due to retained faeces, might have led to low cardiac output and $P$ sys. This may have led to the absence of pulmonary hypertension. However, in Experiment 3 (table 3), where AMI was given by gavage and the rats were in better condition, there was also no evidence of right ventricular hypertrophy or muscularisation of pulmonary arterioles in the normoxic group. Additional experiments were performed with concomitant chronic hypoxia, which itself causes pulmonary hypertension and is an accompanying feature of ARDS following TCA overdose. In the chronic hypoxic groups the development of pulmonary hypertension was confirmed by the presence of RV hypertrophy and vascular remodelling, which was unaltered by chronic AMI.

Although the dose regime in Experiments 1 and 3 were similar, the possibility that absorption is more rapid from the peritoneum than the gut, such that the pharmocokinetic profile may have been different leading to a "lower" dosage in the latter, must be considered.

\section{Chronic treatment with iprindole}

After iprindole treatment there was clear evidence of pulmonary hypertension with a significantly raised $P$ pa in Experiment 4a (table 4). In both Experiments $4 \mathrm{a}$ and $\mathrm{b}$, where the dosage was identical but work was carried out in Prague (a) and Sheffield (b), there was evidence of right ventricular hypertrophy $(\mathrm{RV} / \mathrm{LV}+\mathrm{S})$ although this was complicated by lower absolute LV weight associated with reduced body weight in Experiment 4b. However, in both experiments body growth was reduced in the iprindole treated rats with no change in LV/BW. Histological studies were not performed, but ViJeYARATNAM and CorRin [19] showed oedema, swelling of the endothelium and epithelium and macrophage infiltration in rats treated chronically with large doses of iprindole.

\section{Anorectic drugs}

In a parallel study performed by this group on two anorectic drugs (fenfluramine and chlorphentermine) with similar chemical and biochemical properties to tricyclic antidepressants [3], it was shown that given acutely, they also lead to persistent rises in pulmonary artery pressue. They modified angiotensin converting enzyme activity and pressor effects of serotonin and noradrenaline. There is evidence that both tricyclic antidepressants and fenfluramines inhibit potassium channels $[20,21]$, a postulated mechanism for fenfluramine-induced pulmonary vasoconstriction and development of pulmonary hypertension [21, 22]. Analysis of the similarities and differences between anorectics and tricyclic antidepressants may increase understanding of drug-induced damage to the pulmonary circulation.

\section{References}

1. Lullmann-Reich R, Scheid D. Intraalveolar foam cells associated with lipidosis-like alterations in lung and liver of rats treated with tricyclic psychotropic drugs. Virchow's Archiv (cell pathol) 1975; 19: 255-268.

2. Hucker HB, Porter CC. Studies on the metabolism of amitriptyline. Fed Proc 1961; 20: 172.

3. Liu X, Emery CJ, Barer GR. Pulmonary vasomotor effects of an anorectic drug and an antidepressant. Eur Respir J 1995; 8: 467S.

4. Barer GR, Howard P, Shaw JW. Stimulus-response curves for the pulmonary vascular bed to hypoxia and hypercapnia. J Physiol 1970; 211: 139-155.

5. Emery CJ, Bee D, Barer GR. Mechanical properties and reactivity of vessels in isolated perfused lungs of chronically hypoxic rats. Clin Sci 1981; 61: 569-580.

6. Herget J, Palecek F. Pulmonary artery blood pressure in closed chest rats. Changes after catecholamines, histamine and serotonin. Arch Int Pharmacodyne Ther 1972; 198: 107-117.

7. Hunter C, Barer GR, Shaw JW, Clegg EJ. Growth of the heart and lungs in hypoxic rodents: a model of human hypoxic lung disease. Clin Sci Molecular Med 1974; 46: 375-391.

8. Barer G, Emery C, Stewart A, Bee D, Howard P. Endothelial control of the pulmonary circulation in normal and chronically hypoxic rats. J Physiol 1994; 463: 1-16.

9. Russell P, Wright C, Kapeller K, Barer G, Howard P. Attenuation of chronic hypoxic pulmonary hypertension in rats by cyclooxygenase products and by nitric oxide. Eur Respir J 1993; 6: 1501-1508.

10. Russell PC, Wright CE, Barer GR, Howard P. Histamine-induced pulmonary vasodilatation in the rat-site of action and changes in chronic hypoxia. Eur Respir J 1994; 7: 1138-1144.

11. Crome P, Newman B. Fatal tricyclic antidepressant poisoning. J Roy Soc Med 1979; 72: 649-653.

12. Marshall A, Moore K. Pulmonary disease after amitriptyline overdose. BMJ 1973; 11: 716-717. 
13. Suhra T, Sudo Y, Yoshida K. Lung as a reservoir for antidepressants in pharmacokinetic drug interactions. Lancet 1998; 351: 332-335.

14. Varnell RM, Godwin JD, Richardson ML, Vincent JM. Adult respiratory distress syndrome from overdose of tricyclic antidepressants. Radiology 1989; 170: 667670.

15. Roy TM, Ossorio MA, Cipolla LM, Fields CL, Snider HL, Anderson WH. Pulmonary complications after tricyclic antidepressant overdose. Chest 1989; 96: 852856.

16. Shannon M, Lovejoy FH Jr. Pulmonary consequences of severe tricyclic antidepressant ingestion. J Clinical Toxicology 1987; 25: 443-461.

17. Dahlin KL, Lastbom L, Blomgren B, Ryrfeldt A. Acute lung failure induced by tricyclic antidepressants. Toxicol Appl Phanmacol 1997; 146: 309-316.
18. Junod AF, Ody C. Amine uptake and metabolism by endothelium of pig pulmonary artery and aorta. $\mathrm{Am}$ J Physiol 1977; 232: C88-C94.

19. Vijeyaratnam GS, Corrin B. Fine structural alterations in the lungs of iprindole treated rats. $J$ Path 1974; 144: 233-239.

20. Galeotti N, Gheraldim C, Bartolina A. Involvement of potassium channels in amitriptyline and clomipramine analgesia. Neuropharmacolgy 2001; 40: 75-84.

21. Weir EK, Reeve HL, Johnson G, Michelakis ED, Nelson DP, Archer SL. A role for potassium channels in smooth muscle cells and platelets in the etiology of primary pulmonary hypertension. Chest 1998; 114: Suppl. 3, 200S-204S.

22. Archer S, Rich S. Primary pulmonary hypertension: a vascular biology and translational research "Work in progress". Circ 2000; 102: 2781-2791. 